\title{
Summary of Italian marine stages
}

Università di Milano, Dipartimento di Scienze della Terra “Ardito Desio”,via Mangiagalli 34, 20133 Milano, Italy. Email: maria.cita@unimi.it

Eight marine stages for the Quaternary have been defined in Italy starting from 1872 (Sicilian of Doderlein) to 1979 (Selinuntian of Ruggieri and Sprovieri). The definition of all these stages was based essentially on invertebrate paleontology, initially from the study of pelecypods and gastropods, but also of corals, ostracods, benthic foraminifers and, more recently, on planktonic foraminifers and calcareous nannofossils. The 1948 International Geological Congress held in London decided to search for a locality in Italy to define the Neogene/Quaternary boundary in correspondence with the first appearance of the "northern guests" in the Mediterranean. The Vrica section of Calabria was selected for defining the GSSP of the Pleistocene in 1984.

Meanwhile, starting from 1970 the deep-sea record of the western, central and eastern Mediterranean was explored by five Legs of the Deep Sea Drilling Program and Ocean Drilling Program. As a result of integrated, high resolution multidisciplinary investigations of the deep-sea record and of continuous sections exposed on land, a robust chronostratigraphic framework could be constructed. The combination of biochronology, magnetostratigraphy, isotopic stratigraphy, astrocyclostratigraphy, and tephrostratigraphy assures the worldwide correlation potential of the Mediterranean record.

\section{Original definitions}

The sedimentary successions of Quaternary age, particularly of marine facies, are so expanded, well exposed and richly fossiliferous in Italy, that they were well known since the times when Lyell (1833) considered the Newer Pliocene (now Pleistocene) as the unit more similar to the Present, because 90 to $95 \%$ of the taxa recovered from that time interval were still living in the present seas. The best outcrops, whose molluscan faunas were described by Brocchi (1809, 1814), are located on the lower slopes of the Apennines facing the Po Plain. Other fossiliferous exposures that attracted the attention of the scientists for the definition of new stages in the 19th and 20th centuries lie in the southernmost part of the Italian peninsula, in Sicily and in Sardinia.

The marine stages that have been defined in Italy are as follows, in chronological order:

Sicilian (Doderlein, 1872)

Calabrian (Gignoux, 1910)

Tyrrhenian (Issel, 1914)

Milazzian (Dépéret, 1918)

Emilian (Ruggieri \& Selli, 1949)

Santernian (Ruggieri \& Sprovieri, 1975)

Crotonian (Ruggieri et al., 1977)
Selinuntian (Ruggieri \& Sprovieri, 1979).

The definition of all these stages was based essentially on invertebrate paleontology, initially from the study of pelecypods and gastropods, but also of corals, ostracods, benthic foraminifers and, more recently, on planktonic foraminifers and calcareous nannofossils. The Selinuntian Stage was proposed as a superstage replacing the Calabrian, and included from bottom to top the Santernian, characterized by a cold-water fauna, the temperate Emilian and the Sicilian, indicative of very cold conditions. Measured sections, carefully described, are to be found in Gignoux's monograph (1913) but are seldom recorded elsewhere. This notwithstanding several Italian stages have been, and still are reported in various time scales with special reference to the Calabrian, Sicilian and Tyrrhenian.

Meanwhile, the 1948 International Geological Congress held in London decided to search for a locality in Italy to define the Neogene/Quaternary boundary in correspondence with the first appearance of the "northern guests" in the Mediterranean. In 1974 IGCP launched Project 41 (Neogene/Quaternary boundary) with Nikiforova as Project leader, and soon after Selli et al. (1977) proposed the Vrica section in Calabria as a potential Neogene/Quaternarystratotype. The 1982 INQUA Congress, held in Moscow, decided to locate the Neogene /Quaternary boundary at the top of the Olduvai subchron as expressed in the Vrica section at the level of sapropel " $e$ ". No mention was made of the Calabrian stage in the various documents, so that its use declined.

\section{Further developments}

None of the stages listed above meets the prescriptions of the International Commission on Stratigraphy and of the International Stratigraphic Guide (Hedberg, 1976; Cowie, 1986; Remane et al., 1996) so that they were considered as nomina nuda (Vai, 1996). A revision was undertaken in 1990 under the auspices of the Italian Commission on Stratigraphy, as reported in Cita et al. (Episodes, in press) to which reference is made here. After a joint visit to all the sections described in the literature in Sicily and Calabria, attention was concentrated on the Vrica section for the Calabrian, on the Valle di Manche section also from Calabria, and on a coeval section better exposed, more expanded and open marine, from the core of the Apennine foredeep in Basilicata for the post-Calabrian interval. These sections have been investigated with an integrated stratigraphy approach, using all the techniques available, with biochronology as a first (unidirectional) approach, followed by paleomagnetic stratigraphy, isotopic stratigraphy, tephrostratigraphy, and astrocyclostratigraphy as appropriate.

Meanwhile, the deep sea record of the western, central and eastern Mediterranean was explored by the Deep Sea Drilling Program (DSDP Legs 13 and 42A) and of the Ocean Drilling Program (Legs 107,160 and 161). Continuous coring with full recovery was accomplished throughout the Plio-Pleistocene interval in the Tyrrhenian, Balearic, Ionian and Levantine basins (Figure 1), and the detailed studies based on the material recovered served for the definition of biochronologic schemes (Cita, 1975; Rio et al.,1990 inter alias).The eastern Mediterranean, in particular, is of paramount importance because of its peculiar paleogeographic and paleoceanographic situation that results in a highly resolved, unique lithostratigraphic succession with hemipelagic marls as dominant lithology, sapropels and 


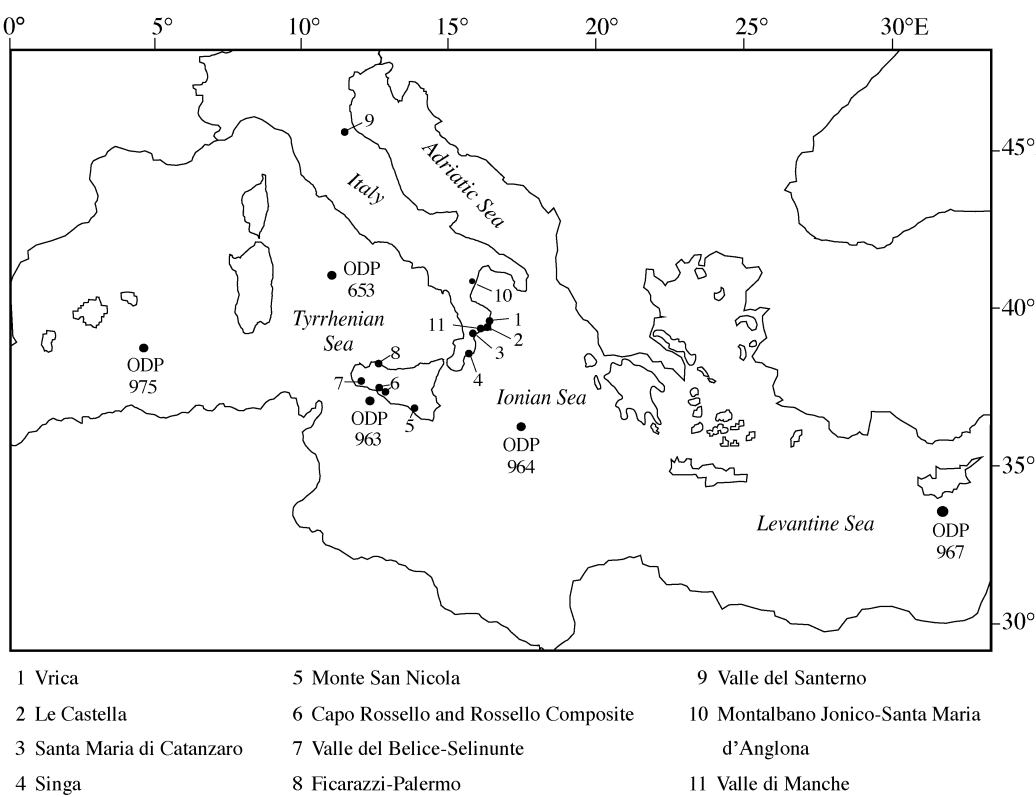

Figure 1 Location of the stratigraphic sections and of DSDP/ODP drillsites mentioned in the text.

tephras as minor, isochronous lithologies. Indeed, sapropels are the sedimentary expression of basin-wide stagnation whereas tephras result from explosive volcanic activity, which is quite frequent due to the presence of two active volcanic arcs in the area. Astrocyclostratigraphy was first applied to these successions starting from the nineties (Hilgen, 1991; Lourens et al., 1996), (see Figure 2).

\section{Summary of present situation}

As of the end of 2007, the CALABRIAN stage has been redefined

(Cita et al., in press; see also Cita et al., 2006) with the Vrica section as type section, and three auxiliary sections on land, plus a deep-sea auxiliary section (unit stratotype sensu Hilgen et al., 2006).

In the Vrica section the GSSP is defined at the top of sapropelic level " $e$ " (primary marker). Secondary markers are considered the position of the GSSP above the last occurrence of Discoaster brouweri and of Globigerinoides obliquus extremus, below the first occurrence of mediumsized Gephyrocapsa and of Globigerinoides tenellus, and in coincidence with the first increase in abundance of left coiling Neogloboquadrina pachyderma. The Vrica GSSP falls about $10 \mathrm{~m}$ below the top of the Olduvai subchron and is correlatable with the top of Marine Isotopic Stage (MIS) 65.

The first two on-land auxiliary sections are that of Singa in Calabria and that of Capo Rossello in Sicily (see Figure 3 and Cita et al., in press). Both these sections duplicate the lower part of the Calabrian, and extend from MIS 65 to MIS 50 or 49, whereas the upper portion of the Vrica section extends up to MIS 37. In other words, the Vrica section does not encompass the entire interval from approximately 1.8 to $0.78 \mathrm{Ma}$ but terminates at about $1.2 \mathrm{Ma}$. The upper part of the Calabrian (see location in Figure 1 and columnar logs with biohorizons in Figure 3) is expressed in the Montalbano section of Basilicata that extends from MIS 37 to MIS 16. The Montalbano section is the third auxiliary section for the Calabrian stage. As a deep-sea reference, the Ionian Sea ODP Site 964 is indicated. All the criteria used, including astrocyclostratigraphy and tephrostratigraphy, allow a precise chronocorrelation.

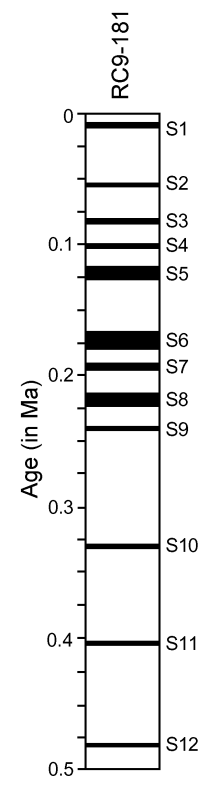

The IONIAN encompasses the interval from approximately $0.78 \mathrm{Ma}$ to approximately $0.13 \mathrm{Ma}$ (from the Matuyama/Brunhes reversal within MIS 19 to the MIS 6/5 boundary or Termination II) and is represented by two sections, that of Valle di Manche in Calabria (Rio et al., 1996; Massari et al., 2002; Capraro et al., 2005) and that of Montalbano in the core of the Apennine foredeep (Cita and Castradori, 1994; Ciaranfi et al., 2000; Ciaranfi and D' Alessandro, 2000; Ciaranfi et al., submitted). Both are suitable for the purpose of identifying the lower boundary and have been investigated in great detail in the last several years. They can be chronocorrelated by means of multiple techniques, including calcareous nannofossil biochronology, palynology, isotopic stratigraphy and tephrostratigraphy. The only advantage of the first is that the magnetostratigraphy is well known, whereas weathering of the well exposed badlands has prevented, until recently, the development of a magnetostratigraphy in the much more expanded Montalbano section, which is $480 \mathrm{~m}$ thick and encompasses all the MIS stages from 37 to 16 (see Ciaranfi et al., submitted). A paleomagnetic study of the Montalbano section is currently in progress (N. Ciaranfi pers. comm. 2007). A perfect auxiliary section in the open sea is represented by ODP Site 963 offshore Capo Rossello. At a water depth of $480 \mathrm{~m}$, it lies at a distance of a few miles from the "Rossello composite" section, that includes the GSSP of the Zanclean and Piacenzian stages and the correlative levels of the Gelasian and Calabrian GSSPs. Multiple coring to the final depth of $206 \mathrm{~m}$ subbottom encountered the Matuyama/Brunhes magnetic reversal at $155 \mathrm{~m}$ subbottom and the Jaramillo subchron at $170 \mathrm{~m}$. The entire succession is devoid of turbidites and has been deposited at a high sedimentation rate, ideally suited for high resolution investigations (see Di Stefano, 1998; Sprovieri et al., 2003; Sprovieri et al., 2006).

TARANTIAN is the name proposed over ten years ago (Cita \& Castradori, 1994, 1995; van Couvering, 1995) for the interval from the MIS 6/5 boundary ( $0.13 \mathrm{Ma}$ ) or Termination II, to the Holocene in substitution of the well known and widely accepted Tyrrhenian. The original definition by Issel (1914) was based on a rich fossil
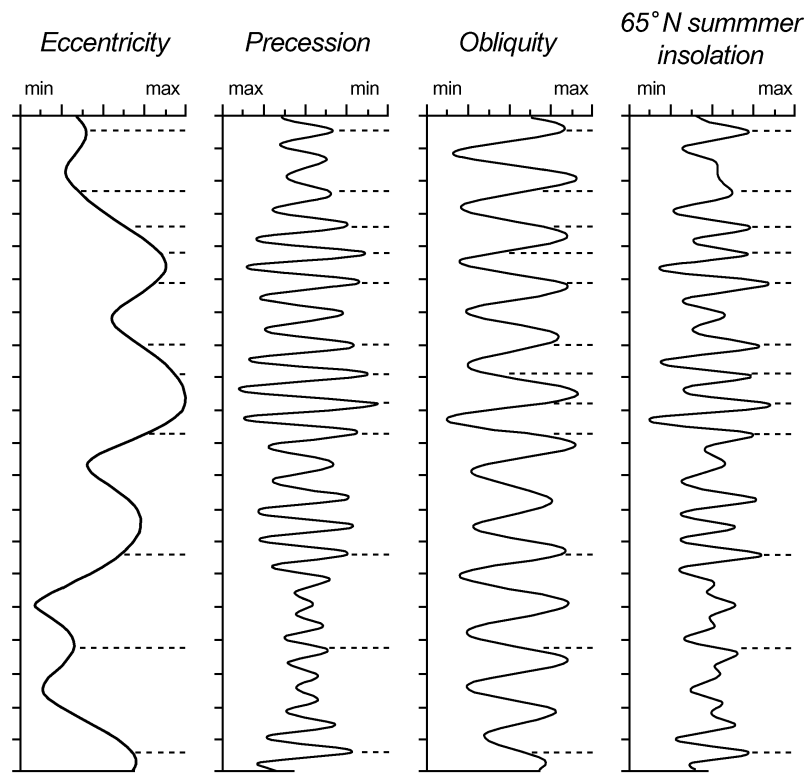

Figure 2 Columnar log of Core RC9-181 which is only $9 \mathrm{~m}$ long, and astrocyclic calibration.of the sapropel layers after Hilgen, 1991 (in Strasser et al., 2006). The MIS 6/5 boundary (Termination II) is recorded immediately underneath sapropel $S 5$, a marker horizon easily identified in all the eastern Mediterranean deep-sea cores, while the MIS 2/1 boundary (Termination I) is recorded underneath sapropel $S 1$. 


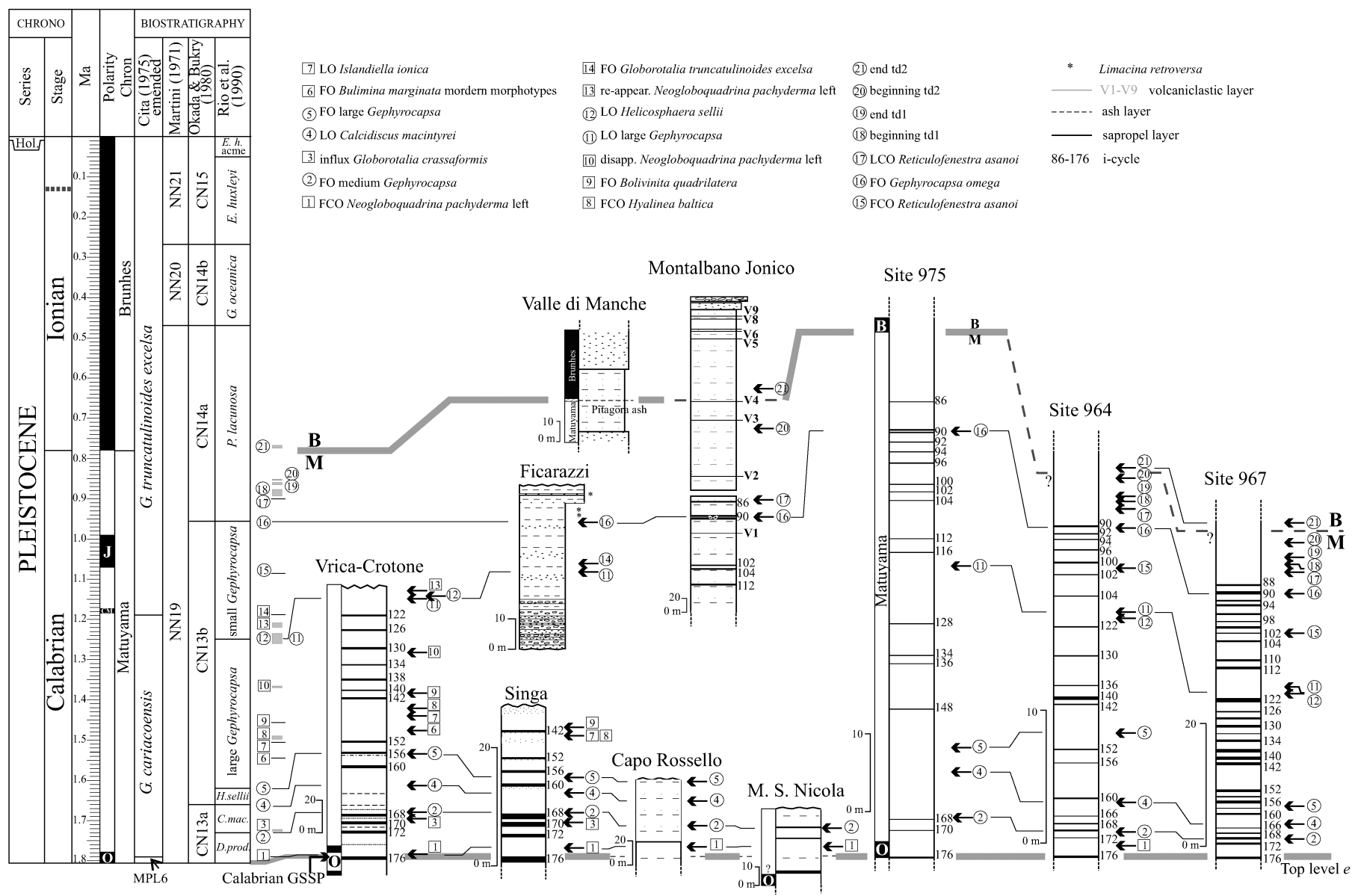

Figure 3 Biochronologic and paleomagnetic correlation of the sections investigated with multiple techniques for the definition of the Calabrian and Ionian stages from the land record and from the deep-sea record.

fauna indicative of tropical conditions with Strombus bubonius, Conus testudinarius, Patella ferruginea, Cladocora cespitosa recorded in raised terraces from several localities around the gulf of Cagliari. But Issel's definition of the Tyrrhenian stage indicated the time interval postdating the Sicilian (of Doderlein, 1872) and predating the Holocene, which in those days (pre-Milankovitch's theory) was conceived as the time that terminated the Neolithic age and caused the extinction of large carnivors in Europe. These criteria are still acceptable today. In other words, the Tyrrhenian included not only the sedimentary expression of the warmest interval of the Pleistocene, that in stable passive margin settings may be represented by just an erosional notch, or by Strombus raised beaches, but also included the last two glaciations. Long excruciating discussions among geomorphologists and marine stratigraphers on the advantages versus disadvantages of keeping an old well rooted name (see Cita et al., 2005) versus introducing a new term resulted in the proposition of the Tarantian. The reason for substituting Tarantian for the well known Tyrrhenian is essentially conceptual more than factual. Indeed the name Tyrrhenian has been commonly and consistently associated with a "warm" interval.

Investigations on the Tarantian, by a large multidisclinary group, are presently very active under the leadership of Fabrizio Antonioli, who presented the state-of the art at the XVIIth INQUA Congress in Cairns, Australia in August 2007. The proposed type section is in the Mare Piccolo di Taranto, is several meters thick, contains richly fossiliferous beach rocks with Strombus and Cladocora cespitosa, suitable for radiometric age determinations. Unlike other late Pleistocene nearshore exposures, the fossiliferous deposits unconformably overlie marine marls of mid Pleistocene age.

\section{Selected references}

Brocchi, G.B., 1809, Conchiologia fossile subappennina con osservazioni geologiche sugli Appennini e sui suoli adiacenti. Giovanni Silvestri, Milano, 1, pp. 1-430.

Brocchi, G.B., 1814, Conchiologia fossile subappennina. Giovanni Silvestri, Milano, 2, pp. 1-556.

Capraro, L., Asioli, A., Backman, J., Bertoldi, R., Channell, J.E.T., Massari, F., and Rio, D., 2005, Climatic patterns revealed by pollen and oxygen isotope records across the Matuyama/Brunhes Boundary in central Mediterranean (Southern Italy): Geological Society of London, Special Publications, v. 247, pp. 159-182.

Ciaranfi, N., Lirer, F., Pelosi N., Lourens, L.J., Maiorano, P., Marino, M., Stefanelli, S., Brilli, M., and Joannin, S., 2007, Astronomical calibration of Mediterranean Montalbano Jonico land section and implication for $\delta^{18} \mathrm{O}$, calcareous nannofossil and tephra records at the Mid-Pleistocene revolution: Terranova (submitted).

Ciaranfi, N., D'Alessandro, A., Girone, A., Maiorano, P., Marino, M., Soldani, D., and Stefanelli, S., 2001, Pleistocene sections in The Montalbano Jonico area and the potential GSSP for Early-Middle Pleistocene in the Lucania Basin (Southern Italy), in Ciaranfi, N., Pasini, G., and Rio, D., eds, The meeting on the Plio/Pleistocene boundary and the Lower/Middle Pleistocene transition: type areas and sections (Bari, 25-29 Sseptember 2000): Memorie di Scienze Geologiche, v. 53, pp. 67-83.

Ciaranfi, N., and D'Alessandro, A., 2005, Overview of the Montalbano Jonico area and section: a proposal for a boundary stratotype for the lowermiddle Pleistocene, Southern Italy Foredeep: Quaternary International, v. 131, pp. 5-10.

Cita, M. B., 1975, Planktonic foraminiferal biozonation of the Mediterranean Pliocene deep sea record. A revision: Rivista Italiana di Paleontologia e Stratigrafia, v. 81, pp. 527-544. 
Cita, M. B., Capraro, L., Ciaranfi, N., Di Stefano, E., Marino, M., Rio, D., Sprovieri, R., and Vai, G. B., 2006, Calabrian and Ionian: A proposal for the definition of Mediterranean stages for the Lower and Middle Pleistocene: Episodes, v. 29, no. 2, pp. 159-182.

Cita, M. B., Capraro, L., Ciaranfi, N., Di Stefano, E., Lirer F., Maiorano P., Marino, M., Raffi I., Rio, D., Sprovieri, R., Stefanelli S., and Vai, G. B., 2007, The Calabrian Stage redefined: Episodes, in press.

Cita, M.B., and Castradori, D., 1994, Workshop on marine sections of Gulf of Taranto (Southern Italy) usable as potential stratotypes for the GSSP of the Lower, Middle and Upper Pleistocene: Il Quaternario, v. 7, pp. 677-692.

Cita, M.B., and Castradori, D., 1995, Rapporto sul Workshop "Marine sections from the Gulf of Taranto (Southern Italy) usable as potential stratotypes for GSSP of the Lower, Middle and Upper Pleistocene": Bollettino della Società Geologica Italiana, v.114, pp. 319-336.

Cita, M.B., Capotondi, L., and Asioli, A., 2005, The Tyrrhenian stage in the Mediterranean: definition, usage and recognition in the deep-sea record. A proposal: Rendiconti Accademia Nazionale dei Lincei, s. 9, v. 16, pp. 297-310

Cowie, J.W., 1986, Guidelines for boundary stratotypes: Episodes, v. 9, no. 2, pp.78-82.

Dépéret, C., 1918, Essai de coordination chronologique des temps quaternaires. Comptes Rendus de l'Academie des Sciences, v. 166, 12, pp. 480-486, Paris.

Di Stefano, E., 1998, Calcareous nannofossil quantitative biostratigraphy of Holes 969E and 963B (Eastern Mediterranean). in Robertson, A.H.F., Emeis, K.C., Richter, C. and Camerlenghi, A., eds, Proceedings of the Ocean Drilling Program, Scientific Results, v. 160, pp. 99-112. College Station, TX (Ocean Drilling Program).

Doderlein, P., 1872, Note illustrative della carta geologica del Modenese e del Reggiano: Memoria III, pp. 74.

Gignoux, M., 1910, Sur la classification du Pliocène et du Quaternarie dans l'Italie du Sud: Comptes: Rendus de l'Academie des Sciences, v. 150, pp. 841-844, Paris.

Gignoux, M., 1913, Les formations marine Pliocènes et Quaternaires dans Italie du Sud et la Sicile: Annales Université de Lyon, n.s., v. 36, pp. $1-633$.

Hedberg, D.H., 1976, International Stratigraphic Guide-A guide to stratigraphic classification, terminology and procedure: John Wiley and Sons, New York, pp. 1-200.

Hilgen, F.J., 1991, Astronomical calibration of Gauss to Matuyama sapropels in the Mediterranean and implication for the Geomagnetic Polarity Time Scale: Earth and Planetary Science Letters, v. 104, pp. 226-244.

Hilgen, F.J., Brinkhuis, H., and Zachariasse, W.J., 2006, Unit stratotypes for global stages: The Neogene perspective: Earth-Science Reviews, v. 74, pp. $113-125$

Issel, A., 1914, Lembi fossiliferi quaternari e recenti nella Sardegna meridionale dal prof. D. Lovisato: Rendiconti Accademia Nazionale dei Lincei, s. 5, v. 23, pp. 759-770.

Lourens, L.J., Antonarakou, A., Hilgen, F.J., Van Hoof, A.A.M., VergnaudGrazzini, C., and Zachariasse, W., 1996, Evaluation of the Plio-Pleistocene astronomical timescale: Paleoceanography, v. 11, pp. 391-413.

Lyell, C., 1833, Principles of Geology, v. 3, John Murray, London, 398 pp.

Massari, F., Rio, D., Sgavetti, M., Prosser, G., D'Alessandro, A., Asioli, A., Capraro, L., Fornaciari, E., and Tateo, F., 2002, Interplay between tectonics and Glacio-eustasy, Pleistocene of the Crotone Basin, Calabria (southern Italy): Bulletin of the American Geological Society, v. 114, pp. 1183-1209.

Remane, J., Bassett, M.G., Cowie, J.W., Gohrbandt, K.H., Lane, H.R. Michelsen, O., and Naiwen, W., 1996, Revised guidelines for the establishment of global chronostratigraphic standards by the International Commission on Stratigraphy (ICS): Episodes, v. 19, pp. 77-81.

Rio, D., Channell, J.E.T., Massari, F., Poli, M.S., Sgavetti, M., D'Alessandro, A., and Prosser, G.,eustasy, 1996, Reading Pleistocene euastasy in a tectonically active siliciclastic shelf setting (Crotone peninsula, southern Italy): Geology, v. 24, pp. 743-746.
Rio, D., Raffi, I., and Villa, G., 1990, Pliocene-Pleistocene calcareous nannofossil distribution patterns in the Western Mediterranean, in Kastens, K.A., Mascle, J., et al. eds, Proceedings of the Ocean Drilling Program, Scientific Results, v. 107, pp. 513-532. College Station, TX (Ocean Drilling Program).

Ruggieri, G., and Selli, R., 1949, Il Pliocene ed il Post Pliocene dell'Emilia: Giornale di Geologia (2), v. 20, pp. 1-14

Ruggieri, G., and Sprovieri, R., 1975, La definizione dello stratotipo del Piano Siciliano e le sue conseguenze: Rivista. Minereraria. Siciliana, v. 26, pp. 151-153.

Ruggieri, G., and Sprovieri, R., 1979, Selinuntiano, nuovo superpiano per il Pleistocene inferiore: Bollettino della Società Geologica Italiana, v. 96, pp. 797-802.

Ruggieri, G., Unti, A., Unti, M., and Moroni, M. A., 1977, La calcarenite di Marsala (Pleistocene inferiore) e i terreni contermini: Bollettino della Società Geologica Italiana, v. 74, pp. 1623-1657.

Selli, R., Accorsi, C.A., Bandini Mazzanti, M., Bertolani Marchetti, D. Bonadonna, F.P., Borsetti, A.M., Cati, F., Colalongo, M.L., d'Onofrio, S. Landini, W., Menesini, E., Mezzetti, R., Pasini, G., Savelli, G., and Tampieri, R., 1977, The Vrica section (Calabria). A potential NeogeneQuaternary boundary stratotype: Giornale di Geologia, v. 41, pp. 181-204.

Sprovieri, R., Di Stefano, E., Incarbona, A., and Gargano, M.E., 2003, A high resolution record of the last deglaciation in the Sicily Channel based on foraminifera and calcareous nannofossil quantitative distribution: Palaeogeography, Palaeoclimatology, Palaeoecology, v. 202, pp. 119-142.

Sprovieri, R., Di Stefano, E., Incarbona, A., and Oppo, W.D., 2006, Suborbital climate variability during Marine Isotopic Stage 5 in the central Mediterranean basin: evidence from calcareous plankton record: Quaternary Science Reviews, v. 25, pp. 2332-2342.

Strasser, A., Hilgen, F.J., Heckel, P.H., et al., 2007, Ciclostratigraphy - concepts, definitions, and applications: Newsletters on Stratigraphy, v. 42, 2, pp. 75-114.

Vai, G.B., 1996, Revisione critico-storica dei piani marini del Quaternario: Servizio Geologico Italiano, Miscellanea, VI, pp. 1-179.

Van Couvering, J.A., 1995, Setting Pleistocene Marine Stages: Geotimes, v. 40 , pp. $10-11$

Maria Cita is Emeritus of Geology at the University of Milano, Italy, and chair of the International Commission on Stratigraphy's Subcommission on Stratigraphic Classification and of the Italian Commission on Stratigraphy. An expert in Marine Geology and in Mediterranean Neogene, she served several times as shipboard scientist in the early days of the Ocean Drilling Program (Legs 2, 13, 40, 47) and has been Project Leader of IGCP Project 96 "Messinian Correlation" (key-Project, 197579). Honorary Fellow of GSA, Honorary Member of INQUA and of the Italian Paleontological Society, member of several academies, she has chaired the Geological Society of Italy and AIQUA.

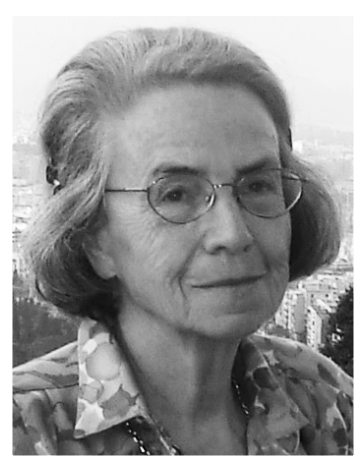

